\title{
THE USE OF GEOGRAPHIC INFORMATION SYSTEM FOR FLOOD PREDICTIONS
}

\author{
Alexandru Tabacaru ${ }^{1}$, ORCID ID: 0000-0002-8555-0882, \\ Livia Nistor-Lopatenco ${ }^{1 *}$, ORCID ID: 0000-0003-3509-648X, \\ lurie Bejan², ORCID ID: 0000-0001-5141-0315, \\ Alexandru Pantaz ${ }^{1}$, ORCID ID: 0000-0002-2471-8848

\begin{abstract}
${ }^{1}$ Technical University of Moldova, Stefan cel Mare Boulevard, 168, Chisinau, Republic of Moldova
2 "Gheorghe Asachi" Technical University of lasi, Bd. Dimitrie Mangeron, nr. 67, Iasi, Romania

*Corresponding author: Livia Nistor-Lopatenco, Livia.nistor@fcgc.utm.md
\end{abstract}

\author{
Received: 03.19.2021 \\ Accepted: 04.19 .21
}

\begin{abstract}
The article examines the issue of using geographic information systems (GIS) and WEBGIS technologies to predict areas likely to be flooded. Probabilistic flood hazard maps ( $0.5 \%, 0.1 \%$ and $1 \%$ flood risks) were used, obtained from a model installation in an area subject to flood risk, in this case, the municipality of Ungheni in the Republic Moldova, which has been flooded in the past. The application of GIS technologies is necessary to prevent floods affecting households, infrastructure and to minimize its effects. For this purpose, were analyzed the previous floods that occurred in the region. Also were applied and overlaid thematic digital maps such as Land Use, river network, DTM, Delineation Methodology of water bodies which represents the transposition of the EU Water Framework Directive 2000/60/EC and at the end were uploaded on an ESRI Web GIS platform http://www.dbga.md/siga.html. The Coordinate system used here was WGS-84.
\end{abstract}

Keywords: geographic information systems, WEBGIS, flood risk, Digital Elevation Model, water body.

\section{Introduction}

Flooding occurs in many parts of the world and cause many losses of life, also damages to the economy, infrastructure, etc., therefore it is important to understand the factors associated with flood incidence in order to be able to manage and to control it.

Moldova is prone to regular floods on its main river courses Prut and Dniester and not only. Due to old inherited flood protection system, the consequences of floods occurring cause serios economic damages to the households and to the country's economy in general.

Floods usually have a relatively short duration and a relatively high peak discharge. It occurs rapidly, generally ranging from several hours to several days from the rainfall depending of the length of the water stream, and sometimes accompanied by landslides, mud flows, bridge collapse, damage to buildings, and fatalities, therefore the areas subject to these disasters must be prepared to cope with it.

However, flood risk can be discussed in terms of two elements: hazard and vulnerability [4]. One of the instruments of the European Union is the Directive 2007/60/EC 
of the European Parliament and of the Council of 23 October 2007 on the assessment and management of flood risks (hereinafter called Flood Directive) is the analysis of flood risks by the creation of maps of flood hazards and risks.

Within the framework of HAZARM cross border project between Technical University of Moldova and the Ioan Cuza Technical University from lasi, Romania will be created a map with the pilot area on both sides of the Prut river banks which will be flooded. For more details, please see Figure 1.

The Digital Elevation Model based on SRTM (Shuttle Radar Topography Mission) with a spatial resolution of $30 \mathrm{~m}$ was used. The flood hazard maps $(0,5 \%, 0,1 \%$ and $1 \%$ probability) were obtained with the use of Infoworks software within The Master Plan for flood risk management planning has been developed under TA support to the Moldova Flood Protection Project funded by the EIB.

The urban plan of Ungheni municipality was obtained in Cad format at a scale of 1:5000, but later converted into .shp format, established the projection, which was used in ArcMap software for its later analysis. These maps were posted on an ArcGIS online platform by using a free account on www.arcgis.com.

\section{The study area}

The Ungheni municipality, with a population of 38000 (2016) inhabitants, located in central-western part of the Republic of Moldova is about $9.45 \mathrm{Km}$ long and $2.3 \mathrm{~km}$ wide, with a total area of $16.4 \mathrm{Km}^{2}$. It is situated on the banks of the Prut transboundary river, bordering with Romania.

The average height is $46 \mathrm{~m}$, minimum 27 and the hills on the eastern side have up to $150 \mathrm{~m}$.

It includes various land use activities including residential, urban, and agricultural as well as road networks. Besides, it represents one of the most important traffic node between Romania and Moldova.

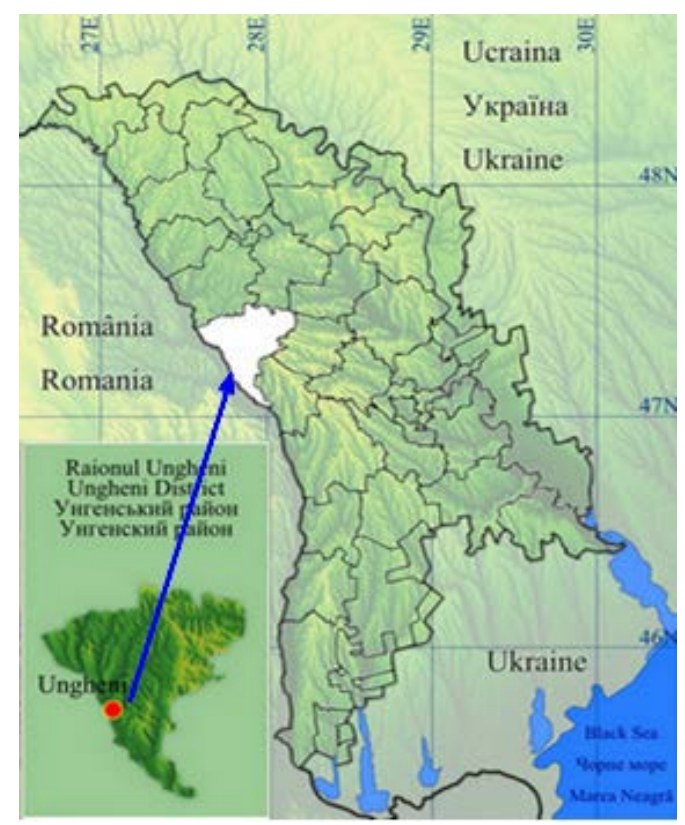

Figure 1. Project area situated on both banks of the transboundary Prut river between Romania (Bosia village) and Republic of Moldova

(Ungheni municipality).

Source- https://en.wikipedia.org/wiki/Ungheni_District. 


\section{Formulation of the problem}

In the years 2008 and 2010 on Prut river occurred flooding which have affected 85 communities in 16 districts. Around 3000 people have been evacuated, including 140 children; 566 houses were completely flooded and an additional 900 are at risk. Casualties have been reported: two deaths and one missing person [5].

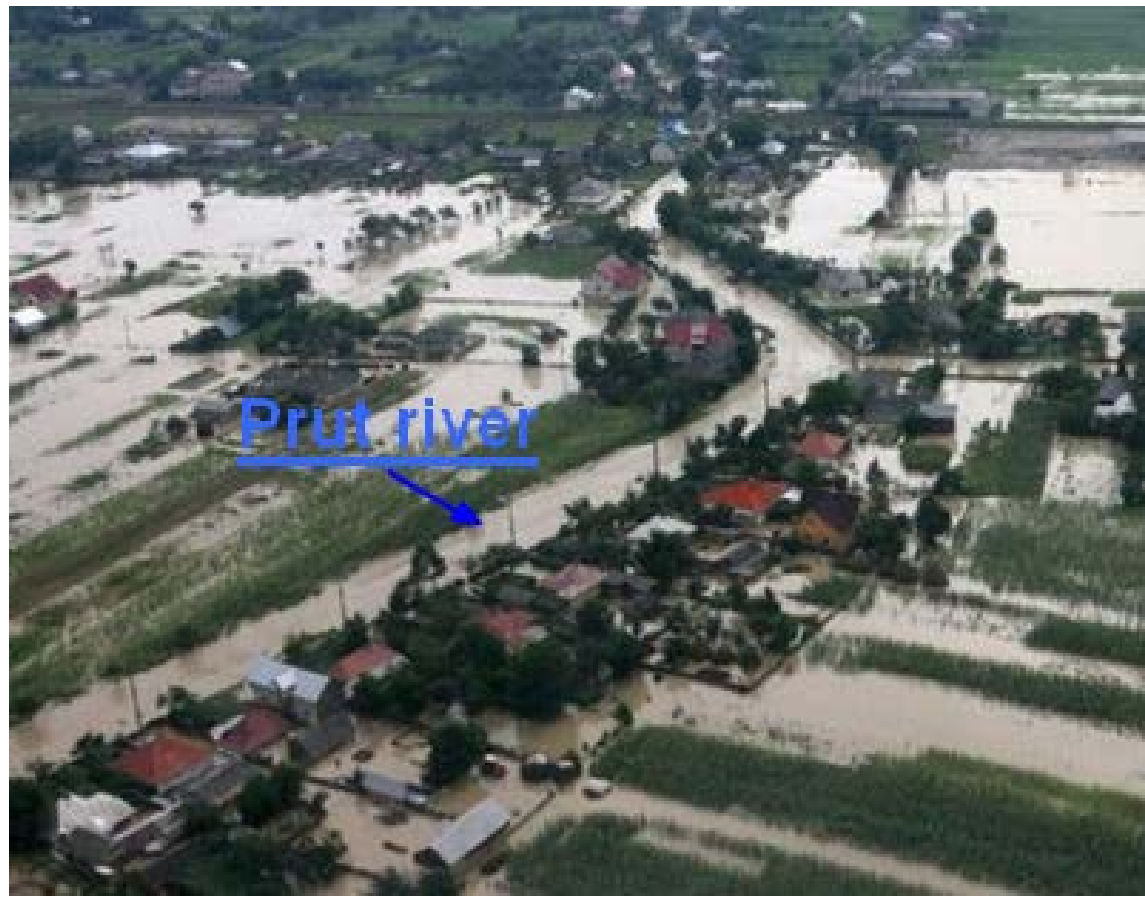

Figure 2. Prut river, flood image.

Source:http://scinetnathaz.net/wpcontent/uploads/2015/06/5OlegBogdevic_Moldova1.pdf.

Flood hazard maps are the first step for flood risk assessment [6 - 8].

To provide modern tools for local and central public authorities for decision making process both for the implementation of Urban Planning and for Emergency Response by creating digital maps which are available online at any time to be used in case of necessity. According to the EU Flood Directive: "All assessments, maps and plans prepared shall be made available to the public.", so the WebGIS represents an especially useful tool to make available all the research, also it would help to people living in flood plains, who may at one point be vulnerable due to their proximity to the river and the amplitude of the flooding.

\section{Analysis of recent research}

The research conducted by [1] have determined that "in the risk map, areas of individual categories of land use are highlighted in which an acceptable risk was exceeded which may result in high vulnerability of the territory." So, depending on the use of a territory we should establish consequently: the highest level should be assigned for the residential areas, at a medium value should be the industries and the infrastructure and at the lowest level should be agricultural parcels.

\section{Results}

Using the ArcMap 10.1 GIS software were overlayed the layers of the Digital Elevation Model, Rivers network, municipal boundaries and the Flood Hazard maps obtained by performing the hydrological modelling with the Infoworks software. 


\section{The Digital Elevation Moldel}

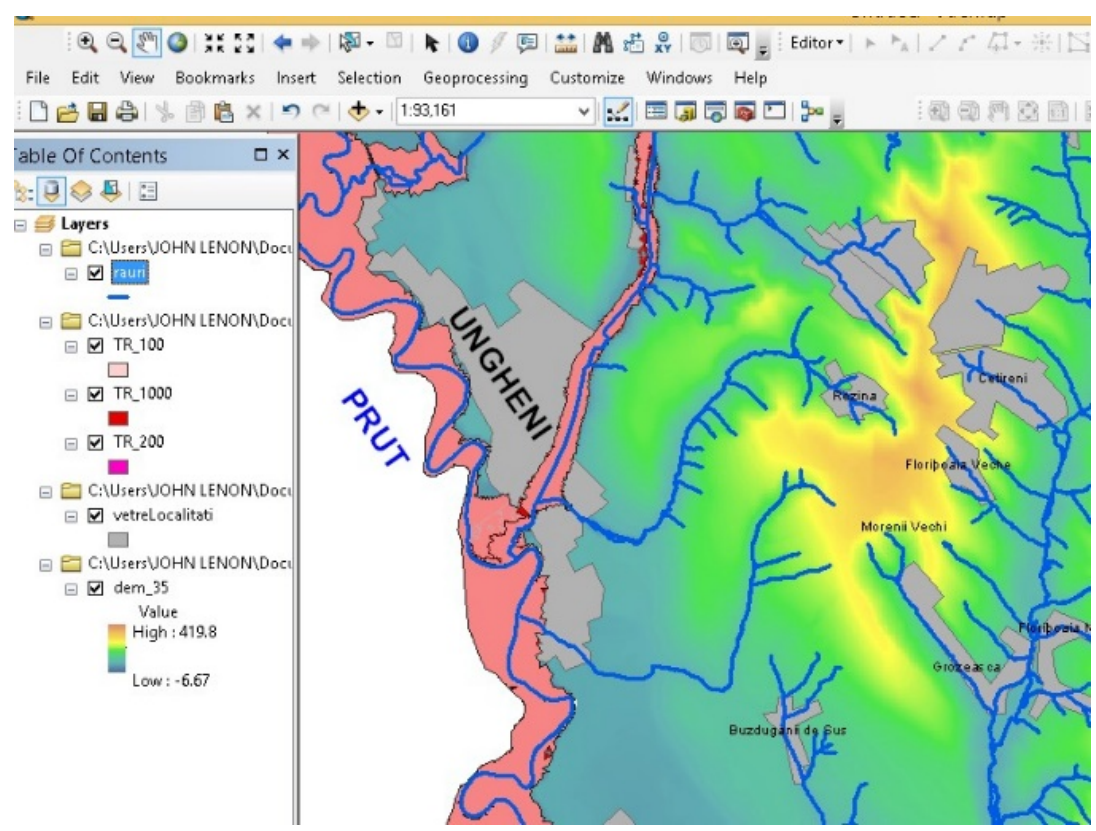

Figure 3. Digital Elevation Model, Flood Risks.

Source: SRTM by NASA.

\section{The Land use maps.}

As one can notice by analyzing the Figure 3 and 4, the southern area of the Ungheni municipality is going to be affected by flood hazard because of the water accumulation both from the Prut river, one of its tributaries and the water reservoir on the course the river Delia.

The next step was to identify the areas subject to flooding by their land use. For that reason, the Land use map was used.

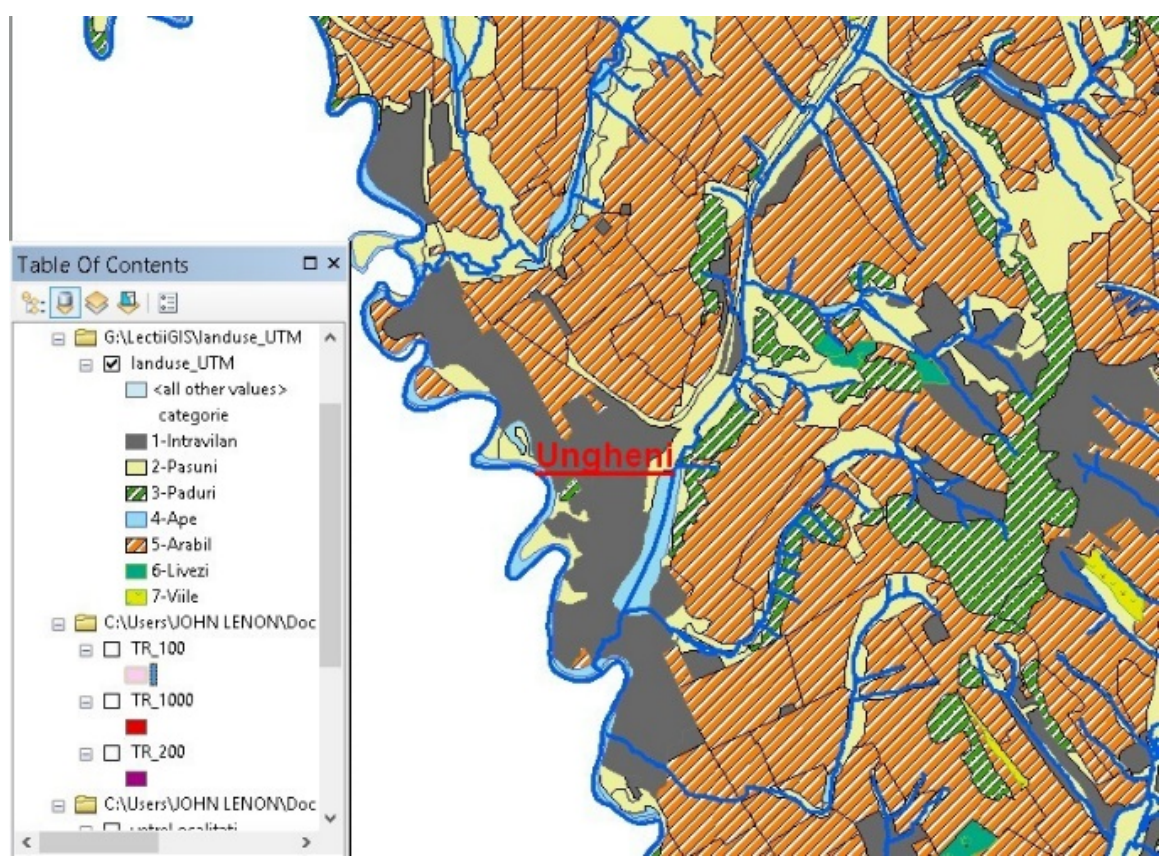

Figure 4. Land Use of Ungheni area.

Source: [11]. 
As one can see in the figure above, the Ungheni municipality is very close to the river Prut and the areas which will be affected are: pasture, arable lands and the residential buildings of the inhabitants.

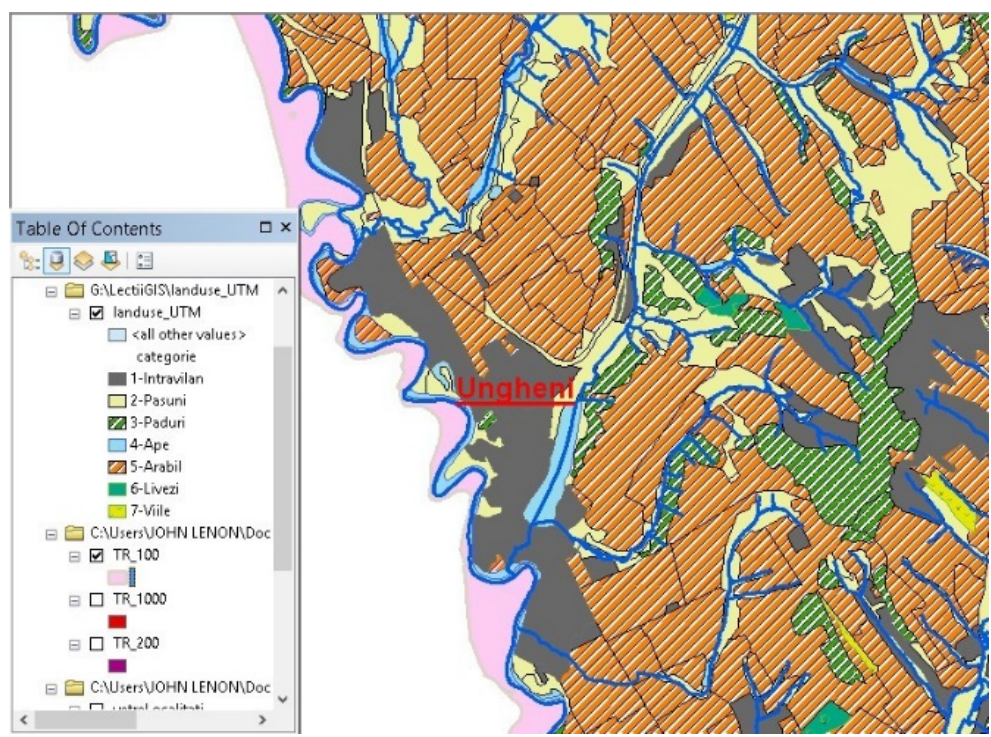

Figure 5. Floods over Land use.

Source: [11].

When we overlay the Flood Hazard Maps with the Land use we can see the areas prone to the Flood events. So, these areas will be affected by floods with the 1 to 100 probability at least.

\section{The Water Body delineation}

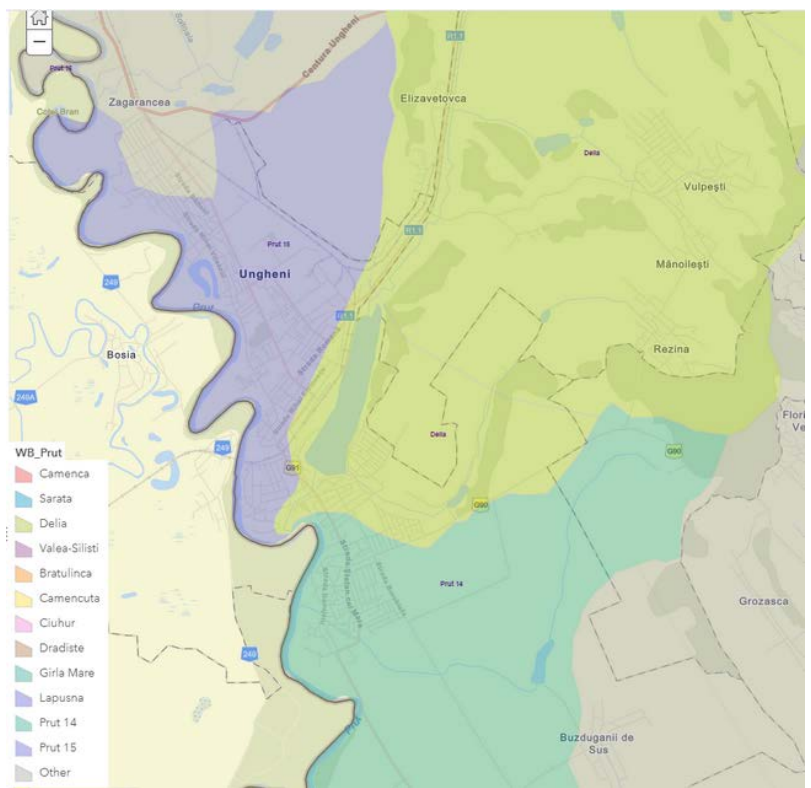

Figure 6. The Water Bodies that intersect the Ungheni municipality.

Source: $h t t p: / / w w w . d b g a . m d / s i g a . h t m l$.

The delineation process of the Water Bodies was performed according to the Delineation Methodology from the Moldovan Water Law Nr. 272 from 23-12-2011 [9]. Each water body should consist of its unique characteristics until it meets another water with different characteristics. In the figure below one can notice that the water body $\mathrm{nr} 1$ 
represents a water stream, represented as a blue line, until it meets a water reservoir, represented as a blue circle and the process goes on according to the same logic.

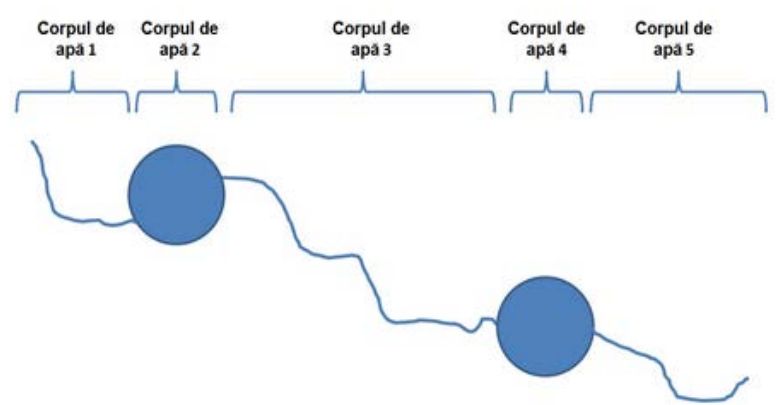

Figure 7. The Delineation of the Water Bodies scheme. Source- $h t t p s: / / w w w . l e g i s . m d /$ cautare/getResults?doc id=23003\&lang=ro.

By analyzing the Figure nr. 6, one can see that the Ungheni municipality is situated on the intersection of the Prut River Basin and its tributary Delia. In total were identified 3 water bodies - Prut 14, Prut 14, and Delia.

\section{River Basins and Flood Hazard maps}

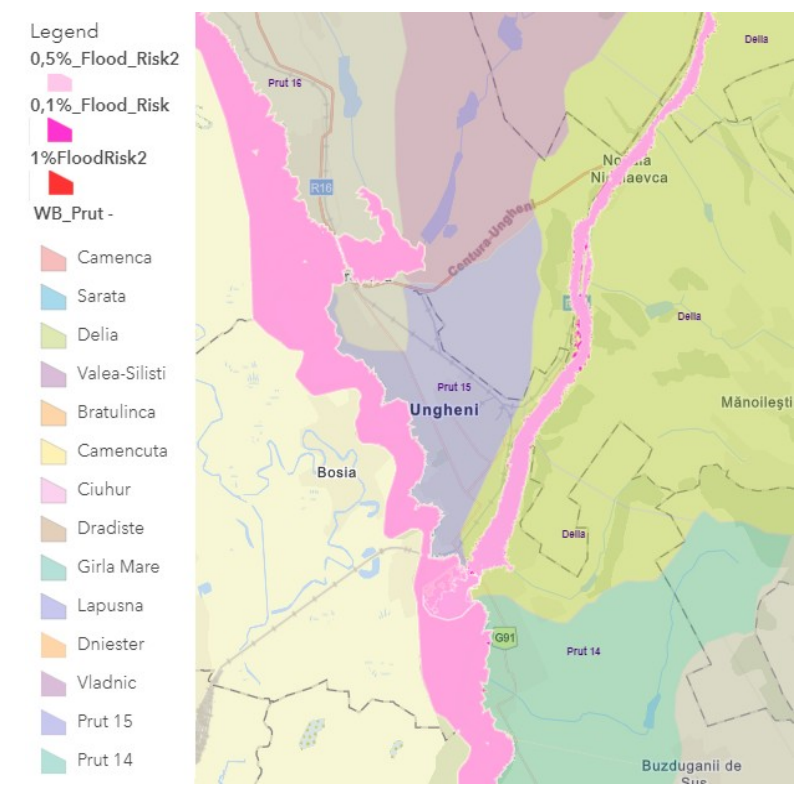

Figure 8. Flood Hazard map and the Water Bodies on Prut Basin.

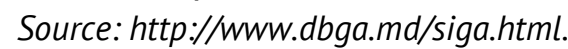

The monitoring and management unit of the WFD is the "water body". It is defined as a discrete and significant element of surface water, which is uniform in type and status [10].

Flood risk management is often an equally resource intensive process; for example, the development of detailed flood risk maps available to the public on a user-friendly geographical information system is costly (Scottish Environment Protection Agency, 2009). But nowadays due to the constant improvements of the research methodologies, technologies it is not that expensive.

"framework for the assessment and management of flood risks, aiming at the reduction of the adverse consequences for human health, the environment, cultural heritage and economic activity." 
WebGIS technologies

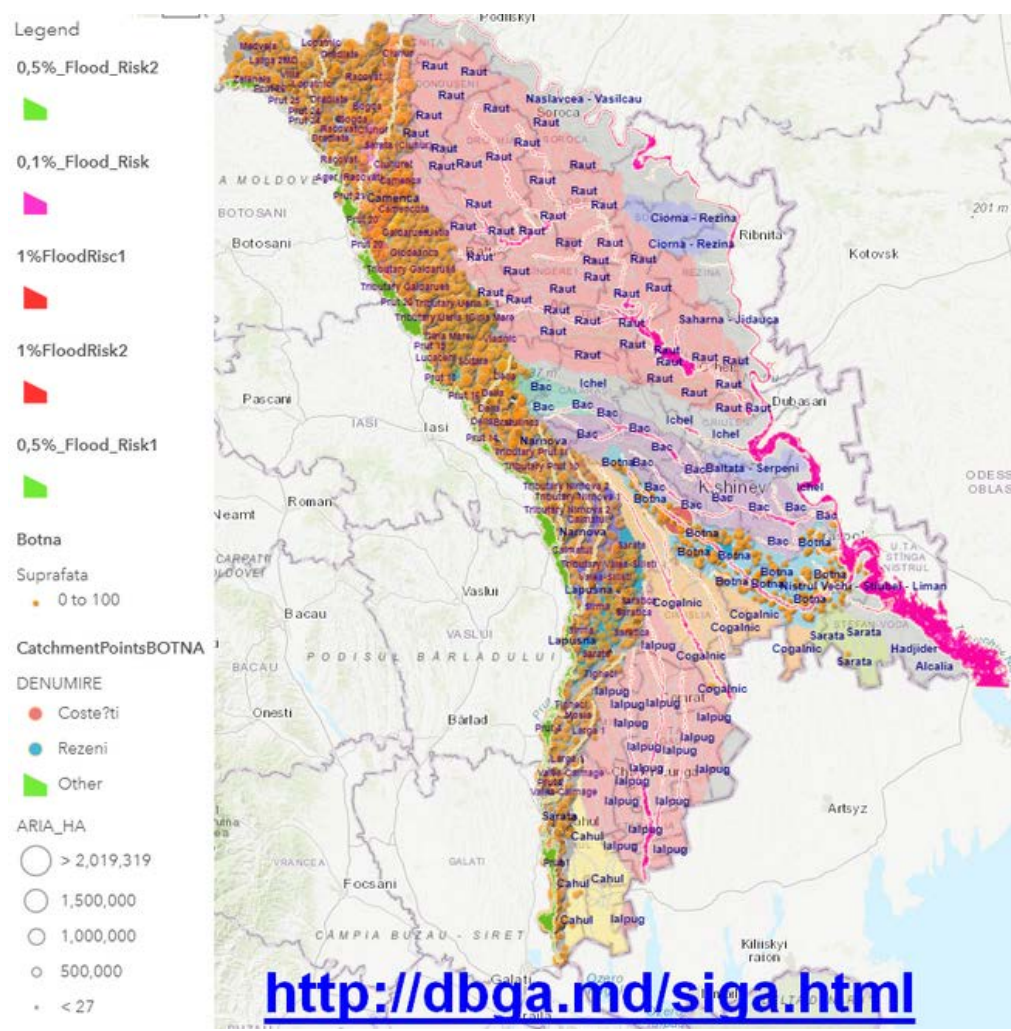

Figure 9. The WebGIS resources.

The obtained GIS data was uploaded on an open account from ESRI www.arcgis.com, called "River Basins, Catchment and Discharge Points in Moldova" and after that the code was embedded into the www.dbga.md/siga.html website for all the stakeholders to be able to see.

\section{Conclusions}

The experimental graphic semiology brings some more results and interesting aspects in the field of risk assessment and distribution. It is helping to improve the graphical layout of our maps, the manageability of the maps as well as the interest of experts, decision makers and layman. Readable maps are important to understand the relevance and the impacts of such maps.

Flood maps only serve as recommendation and unfortunately thew Local and Central Authorities do not take them into account when a flood event is occurring, also the building restrictions etc. are not legally binding. These maps are not included in urban planning and the municipality is not using them when releasing permits for new houses and the people will suffer from flooding at a specific point in time.

One of the basic instruments to cope with possible future flooding's events is the communication and cooperation with the public, it is necessary to solve the legal foundation of flood hazard and risk maps in near future.

Acknowledgments. This publication/material has been produced with the assistance of the European Union. The contents of this publication are the sole responsibility of authors and can in no way be taken to reflect the views of the European Union or of the Joint Operational Programme Romania-Moldova 2014-2020 management structures. 


\section{References}

1. Klemešová K., Kolář M., Andráško I. USING GIS IN THE FLOOD MANAGEMENT - FLOOD MAPS (TROUBKY, CZECH REPUBLIC), Geographia Technica, Vol. 09, Issue 2, 2014, pp 44 to 53

2. Kealeboga K. M., Darka M., François A. Bradford Nickerson Web based Geographic Information Systems for a Flood Emergency Evacuation

3. Vahdettin D., Ozgur K. "Flood Hazard Mapping by Using Geographic Information System and Hydraulic Model: Mert River, Samsun, Turkey", Advances in Meteorology, vol. 2016, Article ID 4891015, 9 pages, 2016. https://doi.org/10.1155/2016/4891015 Date accessed 13-12-2020

4. Dang N.M., Babel M.S., Luong H.T. Evaluation of flood risk parameters in the Day River flood Diversion area, Red River Delta, Vietnam, Nat Hazard, Springer, doi: 10.1007/s11069-010-9558-x, 2010.

5. https://www.euro.who.int/en/health-topics/health-emergencies/from-disaster-preparedness-andresponse/country-work/republic-of-moldova/floods-in-the-republic-of-moldova/floods-moldova Date accessed 29-10-2020

6. Islam M.K., Sado K. Flood Hazard Assessment in Bangladesh Using NOAA AVHRR Data with Geographical Information System. Hydrol Proc 2000;14:605-20.

7. Islam M.K., Sado K. Development of Flood Hazard Maps of Bangladesh Using NOAA-AVHRR Images with GIS. Hydrolog Sci J 2000; 45(3): 337-55.

8. http://www.saudigis.org/FCKFiles/File/8th_GIS_Program/Papers/31_Khaled_Kheder.pdf

9. https://www.legis.md/cautare/getResults?doc_id=23003\&lang=ro Date accessed 05.11.2020

10. https://www.mdpi.com/2073-4441/8/6/217/htm Date accessed 18.12.2020

11. Land use in the Republic of Moldova (monograph). ASEM Publishing House, Chisinau, page 165 [in Romanian]. 